\title{
Ocean Shipping Cartels: A Survey
}

\author{
WILLIAM SJOSTROM* \\ Centre for Policy Studies, National University of Ireland, Cork
}

\begin{abstract}
Liner shipping has been characterized by collusive agreements, called shipping conferences, since its founding in the mid-nineteenth century. This article surveys the competing models of shipping conferences, including monopolizing cartels and destructive competition models, and reviews a variety of their practices to see how much light they can shed on the profitability and efficiency of conferences.
\end{abstract}

\section{Introduction}

Liner shipping is the business of offering common carrier ocean shipping services in international trade. Since it became an important industry in the 1870 s, it has been characterized by various agreements between firms. Historically, since the formation in 1875 of the Calcutta Conference, the primary form of agreement in liner shipping has been the conference system. Variously called liner conferences, shipping conferences, and ocean shipping conferences, they are formal agreements between liner shipping lines on a route, always setting (possibly discriminatory) prices, and sometimes pooling profits or revenues, managing capacity, allocating routes, and offering loyalty discounts. Conferences agreements have been quite successful and in many cases have lasted for years. There were over 150 conferences operating in the world as of 2001(OECD, 2002, p.19). In the last ten to twenty years, conferences have begun to be supplanted by alliances, which are less complete (they do not, for example, set prices) but encompass more broadly defined trade routes.

Section 1 of this survey will review the liner industry (1.1), the conference system (1.2), and the historical origins of the conference system (1.3). Section 2 reviews the primary models that have been used to explain the conference system, including models of monopolizing cartels (2.1) and destructive competition (2.2), as well as a discussion of competition policy in the industry (2.3). Section 3 reviews a variety of practices and alleged practices of conferences, including predatory pricing (3.1), loyalty contracts (3.2), price discrimination (3.3), and price and output fixing (3.4). Finally, section 4 offers a brief conclusion.

* Centre for Policy Studies, National University of Ireland, Cork, 5 Bloomfield Terrace, Western Road, Cork, Ireland. E-mail: w.sjostrom@ucc.ie I am indebted to the editors, Julian Wright and Wayne Talley, for detailed comments and difficult questions. 


\subsection{Liner shipping}

Liner shipping is distinct from tramp shipping. Liners operate as common carriers. ${ }^{1}$ They publish a freight tariff, operate on scheduled routes, and leave at scheduled times regardless of whether the ship has a full load of cargo. They usually carry a large number of smaller packages for a number of different shippers. ${ }^{2}$ Tramp vessels, as distinct from liners, are usually chartered in some form by a shipper to carry a full shipload of cargo. ${ }^{3}$ (Firms offering shipping services, either liner or tramp, are called carriers. Their customers are called shippers.) Both liner and tramp shipping have been subjected to a variety of different kinds of government regulation other than the self-regulation of the conference system (Fox and White, 1997).

It is useful to distinguish bulk from general cargo. Bulk cargo does not have to be packaged before loading; it is simply poured into holds in tramp ships specialized to bulk cargo. General cargo is anything that would be packaged in bags, bales, or boxes, and frequently comes from many small shippers. Since the late 1960s, general cargo has come to be carried largely in containers in specially designed container ships. ${ }^{4}$ Essentially trailers without wheels, a standard container is 8 feet wide and $8 \frac{1}{2}$ feet high, and comes in either twenty or forty foot long versions. They are counted by TEUs (twenty foot equivalents).

The degree of concentration in the liner industry is not known, but there is information about concentration in the container trade. Data on actual cargo carried is normally proprietary, but there is publicly available data on capacity. Based on OECD (2002, p.14), the Herfindahl index for capacity (actual shipments are confidential) is between 202 and 243. CR4 is $21.3 \%$, and CR10 is $36.2 \%$. These measures are worldwide: concentration by route obviously can differ.

\subsection{Conferences}

Conferences are organizations of shipping lines operating on a particular route. For example, the Transpacific Westbound Freight Agreement operates on the route from the U.S. to the Far East and the Indian subcontinent. Some conferences cover traffic in both directions on a route. The Trans Atlantic Conference Agreement, for example, operates in both directions on the route between the U.S. and Northern Europe. There are roughly 150 conferences in operation worldwide as of 2001, ranging in membership from two to forty lines (OECD, 2002, p.19). Their market shares vary. For example, in 2000, the Far East Freight Conference, which operates on the European-Far East trade route, had a capacity share of about $60 \%$, and the Trans Atlantic Conference Agreement has a capacity share of about $46 \%$ (OECD, 2002, p. 22). ${ }^{5}$

It is not clear whether conference routes constitute an economic market. On one hand, ships are movable capital, which implies that individual routes are part of a larger market.

\footnotetext{
${ }^{1}$ A common carrier obligation was imposed on liners in U.S. trades by the 1916 Shipping Act, but was heavily reduced by the Ocean Shipping Reform Act of 1998 (Reitzes and Sheran, 2002), which allowed confidential contracting with individual shippers.

${ }^{2}$ Jansson and Shneerson (1987) is the standard reference on the liner shipping industry.

${ }^{3}$ Stopford (1997, chapter 9) and Branch (1996) are good descriptions of tramp shipping.

${ }^{4}$ Between developed countries, almost all liner trade is containerized; worldwide, it is close to $60 \%$ and growing (Helmick, 2000).

${ }_{5}^{5}$ Actual shipments are normally confidential and unavailable (OECD, 2001, p.16) so only capacity shares are publicly available.
} 
In 1903, Sir Thomas Sutherland, the chairman of the P\&O, told stockholders, commenting on low rates at the time (Smith, 1906a, p.247-48)

It is the world's tonnage at large, the cargo-carrying tonnage of the world at large, which dictates, or rather determines the current rates of freight both by cargo steamers and by mail steamers, and we are simply dragged into the wake of that great movement.

On the other hand, shipping lines may have to incur sunk costs to enter a trade. These could include setting up docking facilities as well as advertising and creating goodwill on a route. Terminals (facilities for docking and for loading and unloading cargo) exclusive to a line (called dedicated terminals) have become more common, especially in the last decade (Haralambides et al., 2002), but ports usually have common user terminals as well. For example, the Port of Seattle has three common user container terminals, each used by an average of nine shipping lines.

Conferences can be either open or closed. In principle, unlike closed conferences, open conferences are required to accept new members. The U.S. Shipping Act of 1916 requires conferences to be open on trade routes to or from the U.S. Elsewhere, conferences are closed (OECD, 2001, p.16). The rules about open conferences are sufficiently ambiguous that open conferences can impose some restrictions on entry by imposing entry fees and by challenging the ability of the entrant to provide common carrier service (Herman, 1983, p.18). McGee (1960, p.267-68) cites eighteen instances where U.S. conferences attempted to block entry to the conference and the blocked entrant appealed to the U.S. Shipping Board (established by the 1916 Shipping Act) or one of its successor agencies, currently the Federal Maritime Commission. In six of those cases, the appeal was rejected.

Conferences issue a freight tariff, which lists the freight rate for each commodity to be shipped. In U.S. trades, the tariff must be open for public inspection, but elsewhere it is often not available. Some commodities rates are listed as open (not set by the conference), or open with a minimum. These are usually bulk commodities, carried by both liners and tramps (Jansson and Shneerson, 1987, p.37). Conferences employ policing agencies to check on adherence to the tariff, and members are fined out of the membership bonds they post (Jansson and Shneerson, 1987, p.41; see Greenhill (1977, p.130) for historical evidence on this point).

Conferences may also allocate output among their members, by either cargo quotas or more commonly sailing quotas. If ships always sailed at the same capacity, which they do not, cargo and sailing quotas would be identical. Sailing quotas are, however, probably easier to enforce. They also may pool revenues and allocate particular ports on a given route (Bennathan and Walters, 1969, p.31; Jansson and Shneerson, 1987, p.41-42). All of these practices have been used by conferences throughout their history. For example, Smith (1906b) reports that in the late nineteenth century and into the beginning of the twentieth century, as part of the Calcutta Conference, the P\&O (Penninsular and Oriental Steam Navigation Company), the B.I. (British India Line), and the Hansa Line ${ }^{6}$ had an agreement about the number of sailings each would make out of Hamburg. Deltas et al., (1999) describes the range of detail in conference agreements.

One alternative to conferences would be merger. Stigler (1968, p.103-106) and Bittlingmayer (1985) have argued that merger is generally a substitute for collusion, but not a perfect substitute because merger increases agency costs. The only known attempt to replace conference organization with a large-scale merger was the founding by J.P. Morgan in 1902 of the disastrously unsuccessful International Mercantile Marine

\footnotetext{
${ }^{6}$ The P\&O and the B.I. were British lines; the Hansa Line was German.
} 
Company (IMM). Capitalized at $\$ 130$ million, almost all of its revenues went to service fixed debt rather than pay dividends, and in 1914, it defaulted on its bonds (Chandler, 1977, p.192). Its stock value fell at roughly 25\% per year (DeLong, 1991, p.219). Temporarily rescued by World War I, it "limped along" until it was finally shut down in 1937 (Chandler, 1977, p.192). ${ }^{7}$

It is not clear why the IMM failed. DeLong (1991) notes that the IMM was the important exception to the usually substantial increase in value provided by Morgan. The IMM overpaid for the firms it purchased (Sabel, 1991, p.241), possibly misled by the boom years of shipping because of the Boer War of 1899-1902 (Fields, 1932, p.271; Sabel, 1991, p.241). It is also possible that Morgan underestimated the prospects of entry by tramp shipping (Fields, 1932, p.279; Sabel, 1991, p.241).

In the last decade, there has been a significant decline in the number of conferences. The number of conferences on file with the U.S. Federal Maritime Commission (restricted to those in U.S. trades) was 99 in 1982 (FMC, 1982), and then dropped from 35 in 1998 to only 19 in 2001 (FMC, 2001, p.25). There has also been an increase in merger activity, although not to the degree of an entire conference or even the bulk of one (Trace, 2002). Recent legislation in the U.S. (Reitzes and Sheran, 2002) and Canada (Brooks, 2002), as well as adverse decisions by the European Commission against conferences in the EC (Stragier, 2002) have made conference organization less attractive. Most serious has been the rise of confidential contracts with shippers that bypass common carrier obligations. Since the passage of the U.S. Shipping Act of 1984, individual carriers in U.S. conferences were allowed to bypass the common carrier obligation to make confidential agreements with individual shippers, although individual conferences could disallow the practice. The Ocean Shipping Reform Act of 1998 went further by prohibiting conferences from disallowing the agreements (Reitzes and Sheran, 2002, p.54). ${ }^{8}$

Beginning in the 1970s, liner consortia (agreements among some conference members to provide a joint service on a route) were used to supplement conferences (Farthing, 1993, p.109-110; Clarke, 1997; OECD, 2001, p.18). More significant has been the rise of the strategic alliance. They were first used in the 1990s (OECD, 2001, p.19), and there is some evidence that conferences are being displaced by alliances, perhaps because of the declining antitrust immunity of conferences. Alliances engage in cross route rationalization, and there is some evidence that the rationalization reduces costs by taking advantage of economies of density (Bergantino and Veenstra, 2002). Unlike conferences, they do not issue a common tariff, but they cover much broader trade routes. Only recently have economists such Ryoo and Thanopoulou (1999), Thanopoulou et al., (1999), and Song and Panayides (2002) begun to study them. Midoro and Pitto (2000) provides a survey and Sheppard and Seidman (2001) provides a review of the legal issues as well as a good description of how alliances function.

\subsection{Historical origins of shipping conferences}

Because sailing vessels are subject to the vagaries of the wind, liner shipping, offering regular, scheduled service, had to wait for the arrival of the steam ship (Boyce, 1995,

\footnotetext{
${ }^{7}$ For good measure, IMM also owned the Titanic.

${ }^{8}$ Fox (1995) attempts to measure the effect of the 1984 Act on conferences, which is discussed in section 2.1. I know of no similar effort for the 1998 Act.
} 
p.24). ${ }^{9}$ Steam did not begin to be a competitor to the sailing ship until the development of the compound engine in the late $1860 \mathrm{~s}$ and the triple expansion engine in the early $1880 \mathrm{~s}$ (Harley, 1971). These developments substantially improved fuel economy and increased speed to about 10-12 knots. The compound engine cut fuel consumption by over half compared to a single cylinder steam engine. Essentially, it involved adding additional cylinders to the steam engine, each additional cylinder reusing steam before it cooled. The increase in fuel economy also expanded the space available for cargo. Steam vessels began to offer regular, scheduled service, i.e., liner service. It is in liner shipping that conferences have thrived. ${ }^{10}$

The U.K.-Calcutta conference is usually described as the first conference, and is certainly the first modern conference. It started in 1875, consisting of five carriers: the P\&O (Peninsular and Oriental Steam Navigation Co.), the B.I. (British India), and the City, Clan, and Anchor Lines (Aldcroft, 1968, p.343). Within a decade or so, the conference extended its coverage of ports of origin from only the U.K. to the rest of northern Europe.

Although the Calcutta Conference was clearly the first modern conference, Sloan (1998) shows that there was a conference from 1850 to 1856 on the North Atlantic involving the British and North American Steam Packet Company (the Cunard Line) and the New York and Liverpool United States Mail Steamship Company (the Collins Line). Dyos and Aldcroft (1969, p.269) assert that Glasgow ship owners were fixing rates with a conference system in the 1860s. In addition, the Transatlantic Shipping Conference was formed in 1868. It was concerned, however, with issues such as uniform bills of lading and improving methods for inspecting cargo, and did not become involved in rate setting until 1902 (Smith, 1906a, p.253). Although conferences are generally associated with international shipping, Armstrong (1991) finds evidence of precursors in British coastal shipping as early as the 1830 s.

In the thirty years following the formation of the U.K.-Calcutta conference, conferences were formed on most of the major trade routes out of the U.K. and northern Europe. The Far East Conference ${ }^{11}$ was founded in 1879 by John Swire, a shipping agent widely viewed as the driving force behind the spread of conferences (Marriner and Hyde, 1967). The Australia conference was started in 1884, the South African conference in 1886, the West African and northern Brazil conferences in 1895, the River Plate conference in 1896, the west coast of South America conference in 1904, and a conference covering the North Atlantic trade around 1900 (Kirkaldy, 1914, p.188; Dyos and Aldcroft, 1969, p.269). Most of these conferences covered the outbound trade from Europe, leaving the inbound trades of mostly bulk commodities to tramp vessels (Marx, 1953, p.47; Dyos and Aldcroft, 1969, p.269).

It is commonly argued by historians of shipping conferences that they were formed in response to excess capacity. A good summary of the conventional view is Greenhill (1998). The common version of this argument is that the opening of the Suez Canal, by shortening the distance between Europe and Asia, created excess capacity, but this version is not supported by the evidence (Sjostrom, 1989b). Sailing vessels could not use the

\footnotetext{
${ }^{9}$ The thirteenth century Venetians operated what can be interpreted as a liner service to the eastern Mediterranean using a combination of oar and sail (Fleming, 2002).

${ }^{10}$ Curiously, sailing vessels belonged to conferences operating on the U.K.-Australia route and the GermanySouth America route (Burley, 1968, p.222), and there were early British coastal conferences involving sailing vessels as well (Armstrong, 1991, p.58). By and large, however, these were exceptions.

${ }^{11}$ It was later renamed the Far East Freight Conference and is still in operation.
} 
Canal. Existing steamships had been built for short routes through the Mediterranean Sea or the Red Sea, and most of them were scrapped after the opening of the Canal. Moreover, after the opening of the Canal, there were increases in net steamship production, which increased later in the 1870s with the introduction of the double expansion engine. The continued production of steamships is inconsistent with industry-wide excess capacity.

If it was not industry-wide excess capacity that triggered the establishment of the conference system, what did trigger it? Marriner and Hyde (1967) draw on the letters of the participants in the early conferences to show that the participants believed they were reacting, not to some specific current event, but to bursts of localized excess capacity as well as to fundamental failures of competition in the industry. This issue will get taken up in section 2 .

Two unsuccessful attempts were made in 1905 to set up conferences in tramp shipping: the Sailing Ship Owners' International Union and the Baltic and White Sea Conference. Both had collapsed by 1908 (McGee, 1960, p.205-206; Abrahamsson, 1980, p.115).

\section{The success of shipping conferences}

There are challenges to explaining shipping conferences. Two in particular are worth noting. First, the conference system has been around for a long time, and many conferences have lasted many years. They do so even though ships are particularly mobile capital, so entry into individual markets seems relatively easy. Second, there is evidence that a substantial proportion of their customers approves of them (Marriner and Hyde, 1967; Ludwick, 1983; Beargie, 1987; U.S. Federal Maritime Commission 1989, 124; Heaver, 1993, p.74; McConville, 1994). ${ }^{12}$ McGee (1960, p.238-39) reports that in various government investigations of the conference system, shippers lined up both in favor of and opposition to the conference system. There is evidence that larger shippers tend to oppose conferences whereas small shippers favor them. ${ }^{13}$ Clarke (1997) reports such a split in late 1990s U.S. disputes over ocean shipping regulation and the passage of the 1998 Ocean Shipping Reform Act. Leubuscher (1963, p.20) notes that at hearings held from 1906 to 1909 by the Royal Commission on Shipping Rings, small shippers favored the conferences, whereas large shippers opposed them. Similarly, Davies (1973, p.155-56) notes that in the pre-WWI West Africa Conference, opposition to conferences came from large shippers who had to charter through the conference, whereas small shippers, who would not be able to profitably charter a ship in any event, favored the conferences. ${ }^{14}$

Explanations for the existence of shipping conferences fall into two categories: cartels and destructive competition. Although economists (e.g., McGee, 1960, Officer, 1971) have usually treated conferences as ordinary cartels, industry participants (Graham, 1981, 1998; Hudson, 1981), maritime economists (Sturmey, 1967), and maritime historians (Hyde, 1967) have frequently treated them as a response to some form of destructive competition.

\footnotetext{
${ }^{12}$ This phenomenon is not confined to liner shipping. Bittlingmayer (1982) offers evidence of customer support for cartels in the late nineteenth century cast iron pipe industry. See also Wiley's (1987) criticism and Bittlingmayer's (1989) response.

${ }^{13}$ I know of no evidence that conferences treat large and small shippers differently.

${ }^{14}$ In principle, a group of small shippers could have collectively chartered a ship. They would have had to agree on a departure date, however, and differences in the value of quick departure would have reduced the group's willingness to pay for a chartered vessel.
} 


\subsection{Cartels}

The argument that conferences are cartels is at least as old as Marshall (1921, p.433), who argued that conferences could act as monopolists because there were substantial scale economies in the industry that led to a small number of firms. ${ }^{15}$ Discussions of shipping conferences that treat them as cartels include McGee (1960) and Bennathan and Walters (1969), and more recently Fox (1992, 1994, 1995), Scott Morton (1997), Clyde and Reitzes (1998), Deltas et al. (1999), and Podolny and Scott Morton (1999).

Four recent attempts have been made to test whether cartel models can explain shipping conferences. Fox $(1992,1995)$ and Clyde and Reitzes (1998) are based on recent data. Deltas et al., (1999) is based on shipping conferences before World War I.

Fox $(1992,1995)$ and Clyde and Reitzes (1998) are attempts to measure the extent to which conferences have market power. Fox (1992) measures the effect of the number of firms in a conference and a conference's market share on freight rates. She finds that freight rates fall when the conference market share falls. She also finds that as the number of conference members rises, freight rates also fall, which is consistent with Stigler's (1968, p.39-63) theory of oligopoly, specifically that increased numbers in a cartel increase the cost of coordination.

Fox (1995) looks at the provision in the U.S. Shipping Act of 1984 that allows conference members to deviate from conference rates on ten days notice. A cartel model would predict that allowing independent action, even though it is public rather than secret price cutting, should undercut conferences because it makes enforcing the conference tariff more difficult. She finds no evidence that the Act made any difference at all to conferences, which is puzzling. Whether the Act would matter would depend on whether the agreement relied on the formal conference agreement and penalties. If tacit collusion were sufficient to maintain the agreement, then the fact that price-cutting had to be public would be sufficient to make independent action unimportant. The reliance on formal organization, however, suggests that tacit collusion was not sufficient.

Clyde and Reitzes (1998) distinguish between increased freight rates because of increased conference market share and because of increased market concentration. They find statistically significant but economically insignificant effects of increased market concentration on freight rates, but contrary to the results in Fox, no effect of increased conference market share on freight rates.

Deltas et al. (1999) look for reasons why a cartel might be easier to negotiate and enforce, arguing that a cartel can then successfully impose stricter, less flexible terms on its members, i.e., better control non-price competition. Enforcement is easier if there is multi-market contact. The basic intuition is that punishment for deviations from a cartel agreement in one market can be carried out in several markets. ${ }^{16}$ They also argue that enforcement is also easier if one or more of the firms have a large global market share. In that case, it is easier for the large firm to transfer ships to a market to carry out punishment.

They start with a sample of 47 pre-World War I conferences. Lacking direct measures of cartel success, they classify cartels as either loose (only fixing prices) and tight

\footnotetext{
${ }^{15}$ Both Lenin and the Marxist historian J.A. Hobson described shipping conferences as vivid examples of the tendency toward the concentration of capital (Cafruny, 1987, p.54).

${ }^{16}$ Their argument should not be confused with the idea that a firm operating in multiple markets can crosssubsidize predatory pricing to prevent destabilizing entry. Boyce (1995, p.97-99), for example, argues that because the International Mercantile Marine ran diversified lines from the U.K. to Canada, the U.S., and Australasia, it could use cross-subsidization to harm smaller, single route firms.
} 
(regulating other components of the agreement, such as output). They then construct an index of interaction between cartels. Their probit equations indicate that both higher interaction between cartels and the presence of a dominant firm lead to more complex (tight) cartels.

Among the anecdotal evidence supporting the cartel hypothesis, one incident stands out. Carriers that entered into alliances with organizations of shippers became credible entrants and were therefore more likely to be admitted into the conference. The Australasian Refrigerated Tonnage Committee, founded sometime between 1909 and 1914, was a conference covering refrigerated cargo shipped from Australia and New Zealand to the U.K. (Burley, 1968, p.222-224). In 1932, at the Imperial Economic Conference in Ottawa, the system of imperial trade preference was strengthened and extended by substantially raising taxes on imports into members of the British Empire from outside (Aldcroft, 1986, p.71). The Blue Star Line had been shipping refrigerated cargo from South America to the U.K. The extension of imperial preference largely eliminated this trade. The Blue Star Line therefore moved its vessels to the Australia-U.K. route and applied for membership in the conference, which was refused. The Blue Star Line arranged an association with a refrigerated meat-exporting group. Three days later, it was admitted into the conference (Burley, 1968, p.237).

\subsection{Destructive competition}

Destructive competition arguments come in two forms. Early versions were analytically unsatisfactory, but they reflected an intuition among people familiar with the industry that the alternative to collusion was not some version of Cournot-Nash or Bertrand-Nash equilibrium. A more sophisticated version of destructive competition arguments, based on the idea of an empty core, has been advanced by Telser $(1978,1987,1994,1996)$ and applied to shipping conferences by Sjostrom (1989a, 1993), Pirrong (1992), and Davies, et al. (1995). ${ }^{17}$

\subsubsection{Early models}

Much of the early work on shipping conferences focused on the idea of destructive or cutthroat competition in liner shipping. The argument focused on high sunk costs, inelastic demand, and the risks to carriers of "overtonnaging" or excess capacity (see Sjostrom, 1986, chapter 4 for an extensive survey of this literature). Marx (1953) is the primary early exponent, Jankowski (1989) makes the argument more formally in a sequential game, and restatements of the argument have come from shipping industry practitioners (Graham 1998) and maritime historians (Hyde, 1967, p.63) as well. In this argument, because a large proportion of cost is sunk, it follows that price would have to fall substantially before sellers would leave the market and therefore the short run market supply curve will tend to be inelastic. In addition, it is often asserted that the demand for liner shipping services is highly inelastic, although there is very little systematic evidence for this. The combination of inelastic supply and demand leads to a highly unstable price. Therefore, carriers are exposed to increased risk of losses, and shippers face substantial uncertainty about freight rates. On this explanation, conferences offer reduced risk to both carriers and shippers.

\footnotetext{
${ }^{17}$ As well as a number of other industries, including cast iron pipe (Bittlingmayer, 1982), aviation (Button, 1996), and the late nineteenth century trusts and mergers (Bittlingmayer, 1985; McWilliams and Keith, 1994).
} 
This explanation suffers from two serious flaws (McGee, 1960, p.272-279; Bennathan and Walters, 1969, p.42-51; Officer, 1971; Larner, 1975). First, if fluctuating prices lead to periods of losses, then they must also lead to periods of offsetting gains. Carriers will not enter unless the risk-adjusted present value of profits is positive. If long run changes in the market occur such that the present value of profits is negative, firms will (efficiently) leave the market, and the losses are their signal to do so. Second, if shippers valued rate stability, they could write forward contracts.

\subsubsection{Theory of the core}

A more recent theoretical revival of the idea of destructive competition is the theory of the core (Telser 1978, 1987, 1994, 1996). Sjostrom (1989a, 1993), Pirrong (1992), and Davies et al. (1995) are applications of the theory to shipping conferences. Button (1996) draws on the work on ocean shipping to extend the argument to the airline industry, which in many ways has similar cost and demand conditions. ${ }^{18}$

The core arises in cooperative game theory, and so it is about coalitions. No group of traders will participate in the market as whole if they can do better themselves in their own coalition. The core is therefore defined as the set of allocations such that no coalition can gain by upset the allocation (Telser, 1994, p.151-52).

The application of the theory of the core to liner shipping focuses attention on avoidable fixed costs and the integer problem. With avoidable fixed costs and rising marginal cost, the relevant average cost curve is U-shaped. No output will be produced at any price below minimum average cost. When price rises to a firm's minimum average cost $\left(p^{*}\right)$, that firm will enter at the output $\mathrm{q}^{*}$ where average cost is minimized, i.e., $\mathrm{q}^{*}=$ $\operatorname{argmin}_{\mathrm{q}} \mathrm{AC}(\mathrm{q})$. The firm will produce $\mathrm{q}>\mathrm{q}^{*}$ if $\mathrm{p}>\mathrm{p}^{*}$. Under perfect competition, the firm's output will therefore be either 0 or $\mathrm{q} \geq \mathrm{q}^{*}$. Suppose firms are identical. Then at $\mathrm{p}^{*}$, industry output must be an integer multiple of $\mathrm{q}^{*}$ (the integer problem). It would be only by chance that demand at $\mathrm{p}^{*}$ would be an integer multiple of $\mathrm{q}^{*}$. It is therefore possible that demand and supply would not intersect. The problem would go away if a firm were willing to produce a fraction of $\mathrm{q}^{*}$, but avoidable fixed costs mean that no firm could profitably do so.

The integer problem is that there cannot be a fraction of a firm. If average cost were everywhere rising, then the efficient firm would be trivially small, and an additional firm could add a trivially small amount of extra output. A U-shaped average cost curve, however, means that entry introduces a lump of extra output.

If inventories were inexpensive, a firm could produce only part of the time and provide a fraction of $\mathrm{q}^{*}$ with inventories. In transportation industries especially, however, output is cargo or passenger space. Once the ship or airplane leaves, empty space is gone, so inventories are impossible. ${ }^{19}$ The only way to create inventories is to have excess capacity, which can lead to an empty core.

The integer problem does not necessarily lead to an empty core, but is likely to under many circumstances. Consider an example attributable to Bittlingmayer (1989). Suppose taxis can carry at most two passengers, and that the cost of a taxi trip is independent of

\footnotetext{
${ }^{18}$ There are two interesting journalistic accounts. Jenkins (1996) applies core theory to the liner shipping industry, and Smith (1995) draws heavily on the academic work on liner shipping to examine the airlines.

${ }^{19}$ Smith's (1995) accounts of conversations with airline executives are similar to the views routinely expressed by people in the liner shipping business (e.g., Graham, 1998), particularly the problem that inventories are extremely expensive.
} 
whether there are zero, one, or two passengers. Admittedly, these assumptions are likely to be factually inaccurate. Most taxis can squeeze in an extra passenger in a pinch, and extra passengers reduce mileage. These assumptions, however, capture the same points that a more realistic but also more complex model would. First, there are some scale economies: once a taxi carries one passenger, the marginal cost of a second is less than the average cost. Second, there are capacity constraints: marginal cost exceeds average cost beyond some output.

Assume each taxi's cost of a trip to the airport is $\$ 5$, and that there are no sunk costs, so the competitive supply of taxi trips is constant at $\$ 5$ per trip. Assume as well, for simplicity, that each possible passenger is willing to pay $\$ 10$ for a taxi trip, so a taxi trip is efficient even if there is only one passenger. Suppose four people want to make a trip to the airport. They will take two cabs, each with two passengers, and each pair of passengers will pay $\$ 5$. How they divide the $\$ 5$ cost between them is irrelevant to the problem.

Suppose instead that only three people, labeled $A_{i}, i=1,2,3$, want to make the trip. The efficient solution is for the three to take two taxis, generating a surplus of $3 \times \$ 10-2 \times \$ 5=$ $\$ 20$. In this case, however, the problem of dividing the $\$ 10$ cost of the two taxis eliminates the possibility of a competitive equilibrium. One possibility is that $A_{1}$ and $A_{2}$ travel together, pay $\$ 2.50$ each, and let $A_{3}$ travel alone and pay $\$ 5$. $A_{3}$, however, could offer to let $A_{1}$ travel with him if $A_{1}$ pays $\$ 1 . A_{3}$ is better off, paying only $\$ 4$ instead of $\$ 5$, and $A_{1}$ is better off, paying only $\$ 1$ instead of $\$ 2.50$. $A_{2}$ is left, however, paying $\$ 5$ instead of $\$ 2.50$, leaving $A_{2}$ in the same position as $A_{3}$ was originally, to upset the allocation.

An equilibrium allocation has to ensure that no coalition $\left(A_{1}, A_{2}\right.$, or $A_{3}$ alone, pairs of $A_{1}$ and $A_{2}, A_{1}$ and $A_{3}$, or $A_{2}$ and $A_{3}$, or the grand coalition of $A_{1}, A_{2}$, and $A_{3}$ ) can do better by upsetting the existing allocation. If $X_{i}$ is the surplus to $A_{i}$, then an equilibrium allocation has to satisfy the following constraints:

(1) $X_{i} \geq \$ 5$

(2) $X_{i}+X_{j} \geq \$ 15 ; i \neq j$

(3) $\sum_{i=1}^{3} X_{i} \leq \$ 20$

The first constraint states that any passenger traveling alone can get a surplus of $\$ 5$. The second constraint states that any two passengers traveling together can get a combined surplus of $\$ 15$. The third constraint states that the best all three passengers can get is the surplus from the efficient solution of traveling in two taxis, which is \$20. Summing all three combinations in the second constraint implies that $\Sigma X_{i} \geq \$ 22.50$, which is inconsistent with the third constraint. The core is empty. In this example, $q^{*}=2$, and if demand is not a multiple of two, the core is empty.

As the market gets larger, the gap between an empty and a non-empty core gets smaller (Telser, 1994, p.159). If it is costless to form coalitions, market size has no bearing on status of the core. Sjostrom (1989a), however, shows that if there are any transactions costs to coalition formation, then the core is less likely to be empty as the market gets bigger, and finds evidence for this result in west coast markets in the U.S.

The absence of equilibrium in market exchange poses a problem for the participants in the market, both buyers and sellers, because it necessarily raises the costs of contracting. Sellers will try to protect themselves from the consequences of the integer problem by selecting technology with lower capacity and higher costs (Telser, 1987, chapter 3; McWilliams, 1990). It is therefore in the mutual interests of buyers and sellers to find a 
way to achieve an allocation through non-market means. It remains true that an individual buyer or seller has an incentive to disrupt the allocation, just as in a cartel model. Unlike a cartel model, however, buyers as a group do not have an incentive to assist the deviating party.

Bittlingmayer's example suggests two of the more interesting implications of the model of the empty core. First, it is worth noting that there are ways of resolving the problem. For example, if the three passengers were friends, they might simply split the cost three ways because an attempt by two of them to exclude the third would result in the loss of a valuable friendship. Alternatively, there might be a social custom, the violation of which would result in being ostracized, dictating that in such cases there be some fair division of the cost. It is important, however, to recognize that these methods of resolving the problem are not market solutions. This implies that collusion may be a means of resolving the problem of an empty core, although merger and vertical integration may be alternatives.

Second, suppose there were sunk entry costs. Then the necessity of earning a return on the initial sunk investment, aggravated by the prospect of facing the costs of an empty core, would limit entry. In the example, suppose there are only three taxis. Then there is an empty core if demand is three or five, but not otherwise. If demand were seven or greater, because capacity is only six, competition would drive the price up to the reservation price of $\$ 10$, and only six passengers would travel. The empty core would only occur when demand was low, for example if the industry were in decline or if demand were a low draw from a high variance distribution.

Two systematic tests of the empty core model have been made. Sjostrom (1989) focuses primarily on demand conditions. Two important results are that increased conference market share raises output and that conferences are more dominant when demand is more variable, both consistent with an empty core and contrary to a monopoly model. Sjostrom does not specify the precise mechanism whereby increased share increases output. Given the result in Clyde and Reitzes (1998) that increased market share has a trivially positive effect on freight rates, the increased output presumably comes from less costly contracting and more efficient production.

Pirrong (1992) focuses on measuring the assumptions of the model, providing evidence of rising marginal cost and U-shaped average cost curves (implying fixed costs). With cost data from the routes to Europe from the North and South Atlantic ports of the U.S., he estimates alternative cost functions. Of particular interest is his successful use of the semilogarithmic cost function, with the form (simplifying from Pirrong) $\ln C=\beta_{0}+\beta_{1} \mathrm{Q}$, where $\mathrm{C}$ is total cost and $\mathrm{Q}$ is output. With $\beta_{1}>0$, the average cost function is U-shaped:

(4) $\frac{\partial(C / Q)}{\partial Q}=\frac{C}{Q^{2}}\left(\beta_{1} Q-1\right)\left\{\begin{array}{l}<0 \text { if } Q<\frac{1}{\beta_{1}} \\ =0 \text { if } Q=\frac{1}{\beta_{1}} \\ >0 \text { if } Q>\frac{1}{\beta_{1}}\end{array}\right.$ 
Pirrong's empirical results imply falling average cost over a substantial range of output, which in turn implies that the integer problem is significant. ${ }^{20} \mathrm{He}$ also discusses why the model implies the absence of conferences in tramp shipping, which is consistent with only two attempts, both unsuccessful, to form conferences in tramp shipping (McGee, 1960, p.205-206; Abrahamsson, 1980, p.115).

In addition to the two systematic tests, there is anecdotal evidence that is consistent with empty core models as well. The founding of conferences is oftentimes associated with economic slumps. For example, the South African Shipping Conference was founded in 1883 by all seven lines offering service from the U.K. to South Africa. The largest members were the Union Line and the Castle Line, and in addition, the conference included Bullard, King \& Co.'s Natal "Direct" Line, Rennie and Sons' Aberdeen "Direct" Line, the Clan Line, the South African Line, and the Imperial Line (Murray, 1953, p.110). The start of the conference coincided with the onset of a major slump in South African international trade (Murray, 1953, p.110; Mitchell, 1982, p.372).

In an empty core model, a primary source of stability for the shipping conference is that shippers as a group gain from cooperation among carriers. As in a cartel model, there are advantages to individual carriers or individual shippers to try to undercut an agreement. In an empty core model, however, shippers as a group benefit from the conference, so they do not gain from undercutting it. This means, for example, that shippers as a group will not combine to undercut loyalty agreements, nor will they combine to combat predatory pricing that is being used to punish carriers that deviate from the conference agreement.

\subsection{The role of competition policy}

Much of the literature about conferences has focused on the role of competition policy, specifically its effects on cartel stability, on efficiency, and on prices. Conference agreements have substantial antitrust immunity in much of the world. In the U.S., antitrust immunity has been the consequence of the Shipping Act of 1916, which established regulation by the Shipping Board and its successors (currently the Federal Maritime Commission), and was clarified and made more explicit in the Shipping Act of 1984 and the Ocean Shipping Reform Act of 1998 (Federal Maritime Commission 1989, 37-38; Reitzes and Sheran, 2002). ${ }^{21}$ In Canada, the Shipping Conferences Exemption Act has protected conferences from antitrust legislation since 1970. Moreover, although Canada's antitrust legislation dates from 1889, no action against shipping conferences has ever been brought under it (Davies, 1994). In the European Community, maritime regulation is determined as of 1987 by Council Regulation $4056 .{ }^{22}$ Antitrust authorities in both the U.S. (Rill, 1991; Nannes, 2000) and the EC (Jenkins, 1996; Gardner, 1997; Stragier 2002) have attempted to reduce the scope of the antitrust exemption. ${ }^{23}$

\footnotetext{
${ }^{20}$ It is not strictly true that falling average cost implies a serious integer problem if there is a sufficiently large flat bottom to the average cost curve, so that total cost is linear over some range. Pirrong, however, finds no evidence of such linearity.

${ }^{21}$ See Sicotte (1999) and Cafruny (1987, chapter 5) for accounts of the passage of the Shipping Act of 1916.

${ }^{22}$ Official Journal of the European Communities, L378/4, December 31, 1986. Ortiz Blanco and van Houtte (1996, chapter 4) give a comprehensive account; Gardner (1997) is a brief summary.

${ }^{23}$ DGIV, the EC Directorate General of the European Commission responsible for competition, is in dispute with the Trans-Atlantic Conference Agreement (and its predecessor, the Trans-Atlantic Agreement), over the interpretation of Regulation 4056. The dispute has been before the European Court of First Instance (Atlantic Container Lines and others v. Commission (T-395/94) [1995] E.C.R. II-595), in which the author served as a consultant to the plaintiffs. Davies, et al. (1995) is the report submitted by the plaintiffs' consultants to the
} 
Critics of antitrust immunity, including McGee (1960, p.207), Walters (1978), Scherer (1979), the U.S. Federal Trade Commission (1989), the U.S. Department of Justice Antitrust Division (1990), Rill (1991), and Fox and White (1997), draw on cartel models. Letwin (1965, p.49), discussing Mogul Steamship Co. v. McGregor, Gow \& Co. et al. ${ }^{24}$ argues that the common law approach of making cartel agreements only unenforceable, rather than actionable, led to an inefficiently large amount of collusion. Although there have been attempts to measure the extent to which conferences raise prices, there has been a disappointing absence of empirical work actually measuring whether the antitrust exemption affects the ability of conferences to raise prices. ${ }^{25}$

Rill (1991, p.8), arguing for an end to antitrust immunity, cites the decline in the U.S. liner fleet as evidence that conferences lack efficiency properties. He does not note, however, that U.S. conferences are subject to far more restrictive regulation than conferences elsewhere. Shortly after the 1958 Isbrandtsen decision (Federal Maritime Board v. Isbrandtsen Company, Inc. 356 U.S., p.481), which prohibited the use of loyalty contracts, ${ }^{26}$ three non-American groups were formed specifically to deal with the difficulties posed for carriers by U.S. policy (Farthing, 1993, p.100-104): the Consultative Shipping Group (CSG), the Committee of European Ship owners (CES), and the Committee of European National Ship owners' Associations (CENSA). ${ }^{27}$ The relevant prediction of Rill's argument is therefore that liner fleets elsewhere should have declined even more than the U.S. fleet, a prediction not yet tested.

Defenders of antitrust immunity (Marx, 1953; Davies et al., 1995; Graham, 1998) agree that it stabilizes conferences, but argue that the conferences are necessary to prevent some form of destructive competition, either by stabilizing prices or restricting entry. Both positions take for granted the proposition that antitrust would destabilize collusive agreements. McCutcheon (1997), however, shows that antitrust laws can make collusion easier. In a repeated game, it is possible to punish cartel cheaters with a price war, but since every member of a cartel loses from a price war, it is cheaper to renegotiate. Because the prospect of renegotiation makes the cartel unenforceable in the first place, antitrust laws that make renegotiation costly can increase the stability of cartels.

\section{Conference practices}

Conferences have a variety of practices that may be able to shed some light on whether they are efficient, and why they succeed or fail. Conferences set prices, often based on loyalty arrangements, but there are also allegations that conferences practice price discrimination and predatory pricing. Conferences also set output restrictions, in the form of sailing restrictions and route allocation.

Court of First Instance for that case. The case was finally settled with the European Commission in November 2002.

${ }^{24} 21$ Q.B.D. 544 (1888). 23 Q.B.D. 598 (1889), [1892] App. Cas. 25

${ }^{25}$ The paucity of evidence supporting the proposition that antitrust improves performance in any industry is discussed in McChesney and Shughart (1995) and Sjostrom (1998).

${ }^{26}$ The decision was reversed by legislation in 1961 (Clarke, 1997, p.18).

${ }^{27}$ CSG was established by governments of the traditional European maritime nations and Japan. Carriers created CES and CENSA, which were merged in 1974 to form the Council of European and Japanese National Ship owners' Associations (still curiously called CENSA) 


\subsection{Predatory pricing}

The most common allegation of predatory pricing revolved around the use of "fighting ships". The conference would, in response to an entrant, lower the rates on one of its vessels to compete with the entrant until the entrant lost money and left the market. McGee (1960) casts doubt on the use of fighting ships, but Yamey (1972) cites the opinion in Mogul Steamship Co. v. McGregor, Gow \& co. et al. for an example of the use of fighting ships. Mogul Steamship Co. is the best known instance of a claim of predatory pricing in liner shipping. Useful discussions can be found in Letwin (1965, p.49-51) and Yamey (1972). Its legal fame rests on the Court's decision that under common law, agreements in restraint of trade (which the Court judged the conference to be) are unenforceable but not actionable.

McGee (1960) remains an influential analysis of shipping conferences as monopoly devices. McGee (1960, p.234) dismissed fighting ships as normal instances of competition, rather than predatory pricing, and cast doubt on the proposition that fighting ships could be or were successfully used for predatory pricing. Yamey (1972) discusses the opinion in Mogul as a counterexample. It is not clear, however, from Yamey's discussion whether predatory pricing in this case was successful. When, in 1885, Mogul sent two ships to Hankow, an inland port on the Yang-tse River (another non-conference firm sent a ship as well), the China conference responded by sending ships to Hankow, inducing a fall in rates, which the Court in Mogul described as unprofitable. On the other hand, the two Mogul ships and the third independent ship sailed sufficiently full that they did not have to carry ballast (material not earning freight carried to stabilize the ship when there is too little cargo), whereas some of the conference ships sailed empty. Although Mogul was not admitted to the China conference, it was given some landing rights on the Yang-tse.

Two recent contributions to our understanding of the ways in which conferences may have used predatory pricing to control entry are Scott Morton (1997) and Podolny and Scott Morton (1999). Scott Morton, studying pre-World War I conferences, finds evidence supporting the "long purse" theory of predation, whereby firms can profitably engage in predation if their financial resources are large relative to the prey. A long purse theory requires that capital markets are sufficiently costly that the prey cannot gain access to capital to survive the price war, whereas the predator can, most likely because the predator already owns larger liquid assets before the war commences (Bork, 1978, p.147-148; McGee, 1980).

Podolny and Scott Morton (1999) extend Scott Morton's (1997) results primarily by finding that entrants with high social status were less likely to be preyed upon. The argument is that the social status of the entrant is a measure of the extent to which an entrant could be relied upon to cooperate with the conference. They also show that the effect of social status declined with the age of the entering firm. This is consistent with the idea that information about a firm becomes more public over time and therefore the conference had less need to rely on social status as a proxy.

The results of Scott Morton (1997) and Podolny and Scott Morton (1999) are consistent with the discussion in Boyce $(1995,97-99)$ of the International Mercantile Marine (IMM), a combination of five transatlantic lines sponsored by J.P. Morgan that was formed in the period 1900-1902. The IMM had alliances with two German lines, Norddeutscher Lloyd (NDL) and the Hamburg Amerika Line (HAPAG), with whom it had a ten-year route allocation agreement. Boyce (1995, p.98) argues that IMM's connection to Morgan gave it access to "abundant capital". 


\subsection{Loyalty contracts}

Conferences use two kinds of loyalty contracts: the dual rate contract (sometimes called contract rates) and the deferred rebate. Under a dual rate system, the shipper signs an agreement to deal exclusively with the conference, and in turn receives a discount on the freight rate. If the shipper uses a non-conference carrier, the conference imposes a fine. Under a deferred rebate system, if the shipper deals exclusively with the conference for, say, six months (the typical length of time), and then deals exclusively with the conference for next six months, the shipper receives a rebate of an agreed proportion of his freight bill from the first six months. The deferred rebate was a novel contract first introduced successfully by the U.K.-Calcutta Conference in 1877 (Marshall, 1921, p.439; Marx, 1953, p.46-47) after being proposed in 1873 on the Yang-tse River trade (Marriner and Hyde, 1967, p.156-57) ${ }^{28}$ The deferred rebate system was prohibited in U.S. trades by the 1916 Shipping Act.

Under both systems, the conference must monitor its customers to determine whether the contract has been broken. There is evidence the contracts have become largely unenforceable in recent decades. ${ }^{29}$ There are two distinctions between the two systems. First, under the deferred rebate system, the shipper loses interest on the price cut. Second, the conference incurs lower enforcement costs with the deferred rebate because it is returning money, rather than trying to collect it (McGee, 1960, p.232-35). Perhaps because of these differences, discounts under deferred rebates tended to be larger than under dual rate contracts, typically double the size (Marx, 1953, p.201-202).

Whichever system a conference used, deferred rebate and dual rate systems usually applied to only certain commodities. For example, the Far East Conference introduced the deferred rebate when it was formed in 1879 , but certain bulk commodities such as rice and silk were excluded from the loyalty arrangement (Hyde, 1957, p.60-61). Moreover, the loyalty requirement was typically waived if the conference were unable to provide sufficient capacity within a reasonable time (Marx, 1953, p.203).

Loyalty contracts are designed to encourage customers to use a particular seller exclusively. The shipper is charged a lower price in exchange for dealing exclusively with the conference. One question is whether they serve to exclude new entry, as the European Court of Justice asserted about the vitamin industry in Hoffmann La Roche v. Commission, [1979] ECR 461, or whether they serve to reduce costs by gaining economies of regularity, such as easier planning. A second question is, assuming they serve to exclude entry, whether such exclusion is efficient.

Lewis (1949, p.72) suggests, and Bork (1978, p.326-328) shows, that under constant marginal costs, loyalty contracts are an unprofitable method of deterring entry. Lewis (1949, p.81-83) cites several instances outside of ocean shipping where rebates were used unsuccessfully to exclude entry. Bork (1978, p.326-328), moreover, shows that the customers who are most deterred from dealing with the entrant are those the conference least wants to deter, i.e., those owed the largest rebate. Nevertheless, Lewis (1949, p.83) and Letwin (1965, p.149) suggest, and Sjostrom (1988) and Yong (1996) show, that they can exclude an entrant that is constrained in its ability to offer a service of sufficiently high frequency to satisfy shipper demand. Whether the exclusion is efficient, however, is in

\footnotetext{
${ }^{28}$ Marshall (1921, p.626) notes that its use spread to other British industries, and Levy (1935, p.193-4) discusses its use by German cartels.

${ }^{29}$ Grossman (1956, p.75) offers estimates of violations of the loyalty agreements of 5-15\% of shippers. Bird (1988) offers survey evidence on the fairly extensive degree of cheating on loyalty agreements.
} 
dispute. Sjostrom argues that successful exclusion is efficient; Yong offers a very postChicago "it depends". Lewis (1949, p.71-72) and Boyce (1995) argue that loyalty contracts may have been cost reducing. They reduced uncertainty for conference members by ensuring them a less variable flow of cargo, which was particularly valuable given the cost structure that made full ships particularly attractive. The evidence is mixed. In reviews of various investigations by different U.S. and U.K. governments into the conferences system, (Gordon, 1969, p.98) finds evidence that shippers favored dual rate contracts, and Davies (1973, p.110) notes that small shippers favored, but large shippers opposed, the deferred rebate system used by the pre-WWI West Africa Conference. Marín and Sicotte (2003) use an event study based on U.S. shipping lines. They find that dual rate contracts were profitable for shipping conference members, which suggests they were enforceable. They also find they were unprofitable for their large customers, which is consistent with Davies (1973, p.110). They have no evidence on smaller shippers, but they speculate that absent an ability to negotiate for concessions, smaller shippers were even worse off than large shippers.

It was common in the nineteenth century for conferences to prohibit their agents from acting for non-conference lines, even though there were difficulties enforcing the provision (Jones, 1985, p.31), and the practice continues today (Sjostrom, 1986, p.54).

As an alternative to paying shippers to avoid dealing with independents, the entrant could be paid off directly. The Ben Line, owned by Wm. Thomson \& Co., was not a member of the Calcutta Conference, nor did it run any regular service to India. It was, however, heavily involved in the China trade. In 1885, a vessel of the Ben Line, the SS Benledi, planned to stop in Calcutta, mainly to pick up tea shipments to take to the U.K. The Calcutta conference paid the Ben Line $£ 150$ to bypass Calcutta (MacGregor, 1961, p.189-90). Using CPI estimates from Maddison (1991), this converts to approximately $£ 2300$ in 1989. Although the amount seems small, perhaps the extra distance of roughly 1300 nautical miles (Lloyd's of London, 1995, p.iv), meaning 41/2 - 51/2 days of extra traveling, implied a very small gain from temporarily entering the trade.

\subsection{Price discrimination}

Conference freight tariffs have for a long time been detailed and lengthy documents, with different freight rates for each commodity shipped. An important issue of contention is the extent to which those differing rates are the consequence of cost differences or price discrimination. Differences in cost could arise from, inter alia, differences in density (called the stowage factor), difficulties in handling the cargo, insurance, and the need for refrigeration. Differences in transport demand elasticities could arise from differences in the costs of waiting: more valuable and more readily perishable goods would bear a higher freight rate for quick service. Even after the widespread use of containers, which have made cargoes more homogeneous, these tariffs have remained in effect.

Allegations that conferences price discriminate by charging higher freight rates to higher valued commodities are of long standing. One claim is that they are simply attempts to extract additional profits from a monopoly position (McGee, 1960, p.224; Bennathan and Walters, 1969, p.59-64). The alternative view is that conferences price discriminate because the large element of fixed common costs requires price discrimination to cover costs (Jansson and Shneerson, 1987, p.79; Sjostrom, 1992).

On the monopoly interpretation, price discrimination is destabilizing for the conference. Price discrimination makes entry more attractive because entrants are 
encouraged to focus on the high priced end of the market. The conference sacrifices stability and durability in exchange for higher profits now. Besides entry, price discrimination is endangered by the prospects for resale, but resale is difficult in any service industry, and in transport it is possible only if the shipper can successfully deceive the carrier about the contents of the shipment.

On the common cost interpretation, price discrimination increases the stability and durability of the conference because it allows the conference to expand output and therefore is in the joint interests of the conference and shippers as a form of Ramsey pricing. ${ }^{30}$ An important difficulty, however, is that Ramsey pricing is necessary only if marginal cost prices do not cover costs, which means that firms are operating under falling average costs. This seems inconsistent with several firms in a conference. Here, however, the integer problem becomes important. Telser (1978, p.114-117) shows that with Ushaped average cost curves, it is efficient to add an additional producer at a level of demand lower than the level necessary to bring the additional producer into the market under perfect competition.

Figure 1, simplified from Telser (1987, p.114), is the easiest way to see this result. Demand is $\mathrm{BB}^{\prime} . \mathrm{MC}_{1}$ is industry marginal cost with one producer, and $\mathrm{MC}_{2}$ is industry marginal cost with two identical producers. Average cost is U-shaped and reaches a minimum at average cost $\mathrm{AA}^{\prime}$ and output $\mathrm{L}$. With one producer, efficient output is $\mathrm{K}$. At that output, total value (the area under the demand curve) is OBCK. The cost of output $\mathrm{L}$ is OADL, and the cost of the extra output K-L is LDCK. Therefore, total surplus is ABCD.

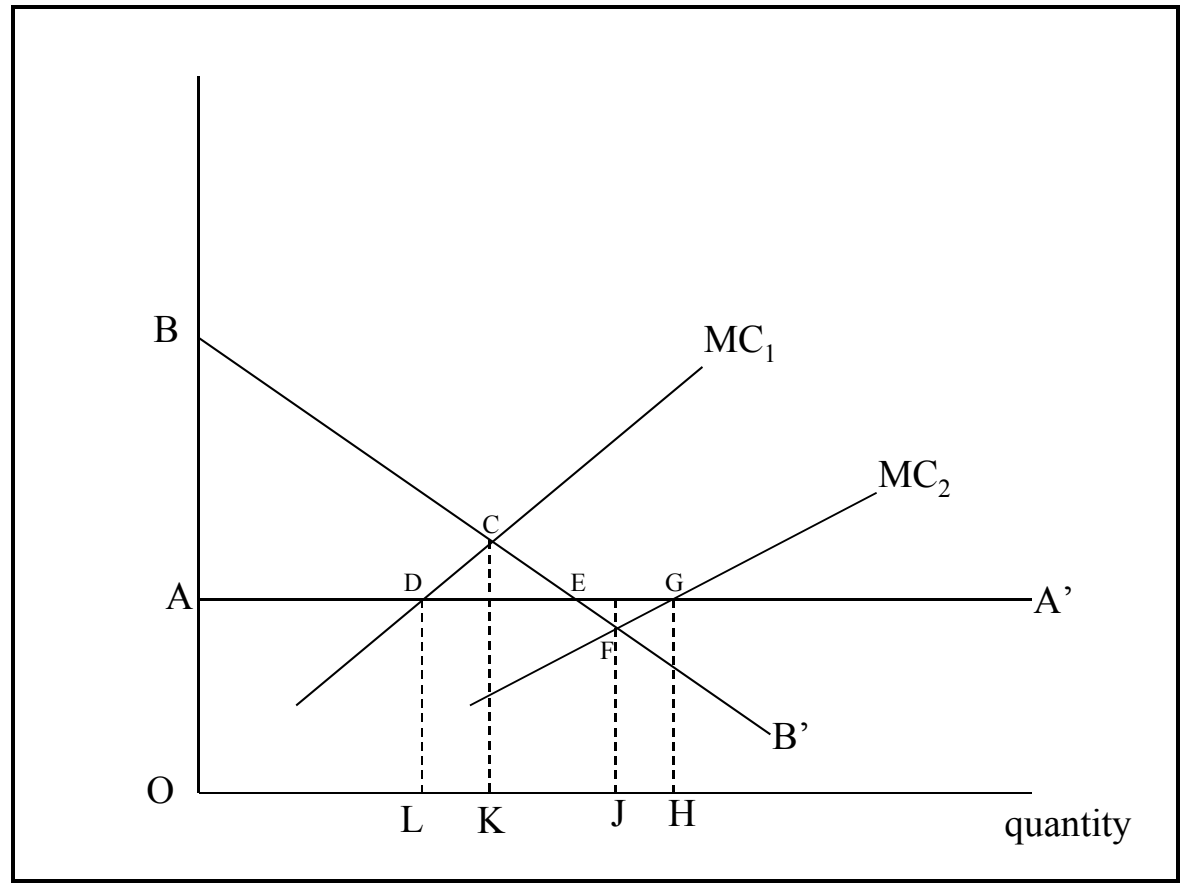

Figure 1: Finding the efficient number of producers

30 See Brown and Sibley (1986, p.39-44) for a description of Ramsey pricing, and Frank (1983) for numerical examples of output increasing discriminatory prices. 
With two producers, efficient output is J. Perfect competition cannot sustain that outcome because with two producers, price would be below A (price would not cover average cost). To see whether it is efficient to add a second producer, we will first calculate total cost if output is $\mathrm{J}$. With output $\mathrm{H}$ (equal to $2 \mathrm{~L}$, because average cost is minimized for one producer at $\mathrm{L}$ and for two producers at $2 \mathrm{~L}=\mathrm{H}$ ), cost is OAGH. If output is reduced from $\mathrm{H}$ to $\mathrm{J}$, costs fall by JFGH. Therefore, the cost of output $\mathrm{J}$ is OAGFJ. Total value is OBFJ, so net surplus is ABE - EFG. The net gain in surplus from switching from one to two producers is therefore CDE - EFG. It is efficient to add a second producer if $\mathrm{CDE}>\mathrm{EFG}$. This occurs for a lower demand than the demand required to sustain a second producer under perfect competition (when EFG falls to zero).

A number of attempts have been made to find out whether conferences practice price discrimination, and the answer remains mostly that we do not know (Sjostrom, 1992). A number of attempts have been made to measure price discrimination by regressing the freight rate for different commodities against, inter alia, the price of the commodity and a group of variables intended to capture differences in transport costs. The fundamental difficulty is identifying variables that capture differences in demand elasticities without also identifying differences in costs. A significant coefficient on commodity price is usually asserted to be evidence of price discrimination. Unfortunately, higher priced goods usually carry higher insurance costs and frequently require more delicate handling. The cost variables, moreover, might include price discrimination elements. For example, refrigerated goods usually carry a higher freight rate. The higher rate may be the result of the extra costs of refrigeration, or the result of the less elastic demand because the goods are perishable. To complicate matters, it could easily include both elements. Without independent information on costs, we have no way of knowing whether we are measuring marginal cost or price discrimination.

Clyde and Reitzes (1998) have made an innovative attempt to separate the effects of market power from cost differences by using panel data (different commodities on fourteen routes over four years) in a fixed effects model. By using dummy variables for each commodity, they effectively control for cost differences. The relevant part of their regression is $r_{i j}=\beta_{1} s_{j}+\beta_{2} s_{j} p_{i j}$, where $r_{i j}$ is the freight rate for commodity $i$ on route $j, s_{j}$ is the conference market share on route $j$, and $p_{i j}$ is the price of commodity $i$ on route $j$. It follows that $\partial \mathrm{r}_{\mathrm{ij}} / \partial \mathrm{s}_{\mathrm{j}}=\beta_{1}+\beta_{2} \mathrm{p}_{\mathrm{ij}}$. If conferences are price discriminating, then a drop in competition from independent carriers (an increase in $\mathrm{s}_{\mathrm{j}}$ ) will not only raise freight rates $\left(\beta_{1}>0\right)$, but will raise them more for higher valued commodities $\left(\beta_{2}>0\right)$. Clyde and Reitzes find no evidence for discriminatory pricing, contrary to the anecdotal evidence in McGee $(1960,224)$ that independent lines focus their entry on high valued commodities.

\subsection{Pricing and output rules}

Conferences not only fix prices, they set both minimum and maximum outputs. It is much easier to make sense of the role of maximum output rules. In a cartel model, maximum output rules prevent price from falling to competitive levels. In an empty core model, a maximum output rule allows for efficient use of capacity (see Telser, 1987, chapter 5 for a rigorous proof).

Why though a minimum output rule? One explanation consistent with both cartel and empty core models is entry deterrence. Entry deterrence is important in both cartel and monopoly models. In cartel models, entry lowers price; in empty core models, entry destroys equilibrium. Fusillo (2003) offers evidence that conference liners create excess 
capacity for strategic entry deterrence. In an open conference system, if conferences are successful in imposing entry barriers to non-conference lines, the entrant may attempt to by-pass those barriers by joining the conference. If the minimum output is set high enough, the entrant may end up expanding capacity on the route to unprofitable levels. This limitpricing strategy requires the conference to commit to the minimum output rules by guaranteeing its sailing schedules. As with any irreversible commitment, however, this would expose the conference to the risks of a mistake. An entrant might overestimate demand and therefore mistakenly enter, leaving the conference with excess capacity (McGee, 1980).

Minimum output rules are also consistent with the efficiency argument, raised in Figure 1 in the previous section, that with large fixed costs, it may be efficient to operate where marginal cost is below average cost.

Alternatively, consistent with a cartel model, the minimum output rule may be a way of excluding small, high cost sellers from the conference. The willingness to adhere to a minimum output may be a way of signaling low costs. Every agreement has to ensure it is not eroded by attracting high cost entrants. ${ }^{31}$

Revenue pooling can be a method of sustaining price discrimination and preventing internal cheating in a cartel. It can also be a means of ensuring low cost production (Letwin, 1965, p.172-78; Wilson, 1962, p.133) by separating the decision about efficient output allocation from individual firm profitability.

\section{$4 \quad$ Concluding remarks}

Far more is known about shipping conferences than only a decade ago. The dispute over whether conferences are cartels or institutions to prevent destructive competition remains. Nevertheless, the theoretical arguments are much clearer than in the past, and are being addressed with more systematic evidence than ever before.

We also know more about the ways in which conferences remain stable by controlling entry. Fusillo (2003) has finally offered systematic evidence that conferences use excess capacity to deter entry. Scott Morton (1997) and Podolny and Scott Morton (1999) have systematically addressed the problem of predatory pricing years after the pioneering work of McGee (1960) and Yamey (1972). Fox (1992) and Clyde and Reitzes (1998) have finally found useful ways of sorting out whether conferences price discriminate. Marín and Sicotte (2003) have finally provided some empirical evidence on loyalty contracts, which had previously been largely an object of purely theoretical interest.

Liner shipping has provided serious and important challenges for the study of industrial organization: sometimes legal and sometimes popular collusion, high avoidable fixed costs, and highly mobile capital. The boom in empirical work on the industry in the last

\footnotetext{
${ }^{31}$ Albert Ballin, the managing director of the Hamburg-America Line (Hapag) wrote in 1914 (Broeze, 1993, p.420):

Especially a very strong and powerful party must continuously bear in mind the question, whether the advantages of relying on the free interplay of market forces would not be far greater than the benefits from inhibiting influence of a conference, which after all flow more to its weaker than its stronger members. Hapag was at the time the world's largest shipping line. Although Ballin was implying that Hapag was among the stronger, there is some evidence (Broeze, 1993, p.421) that it was by no means the most profitable, which is counter-evidence to the idea that minimum output quotas were about excluding high cost entrants.
} 
two decades has provided new insights for economists, and further work offers the promise of substantial new gains.

\section{$5 \quad$ References}

Abrahamsson, B.J. (1980) International Ocean Shipping: Current Concepts and Principles. Westview: Boulder.

Aldcroft, D.H. (1968) “The Mercantile Marine," in D.H. Aldcroft (ed), The Development of British Industry and Foreign Competition 1875-1914: Studies in Industrial Enterprise. University of Toronto Press: Toronto.

Aldcroft, D.H. (1986) The British Economy, vol. 1, The Years of Turmoil 1920-1951. Wheatsheaf Books: Brighton.

Armstrong, J. (1991) "Conferences in British Nineteenth-Century Coastal Shipping," The Mariner's Mirror. 77: 55-65.

Beargie, T. (1987) “Shippers Evenly Divided,” American Shipper, 29: 35-38.

Bennathan, E. and A.A. Walters (1969) The Economics of Ocean Freight Rates. Praeger: New York.

Bergantino, A.S. and A.W. Veenstra (2000) "Interconnection and Co-ordination: An Application of Network Theory to Liner Shipping" International Journal of Maritime Economics, 4: 231-248.

Bird, J. (1988) "Freight Forwarders Speak: The Perception of Route Competition via Seaports in the European Communities Research Project - Part II," Maritime Policy and Management, 15: 107-125.

Bittlingmayer, G. (1982) "Decreasing Average Cost and Competition: A New Look at the Addyston Pipe Case," Journal of Law and Economics, 25: 201-230.

Bittlingmayer, G. (1985) "Did Antitrust Policy Cause the Great Merger Wave?" Journal of Law and Economics, 28: 77-118.

Bittlingmayer, G. (1989) "The Economic Problem of Fixed Costs and What Legal Research Can Contribute," Law and Social Inquiry, 14: 739-62.

Bork, R.H. (1978) The Antitrust Paradox: A Policy at War with Itself. Basic Books: New York.

Boyce, G.H. (1995) Information, Mediation and Institutional Development: The Rise of Large-Scale Enterprise in British Shipping, 1870-1919. Manchester University Press: Manchester.

Branch, A.E. (1996) Elements of Shipping. (ed. 7). Chapman \& Hall: London. 
Broeze, F. (1993) "Shipping Policy and Social-Darwinism: Albert Ballin and the Weltpolitik of the Hamburg-America Line 1886-1914," The Mariner's Mirror, 79: 419436.

Brooks, M.R. (2002) "Liner Shipping Regulation in North America: A Canadian Perspective," International Journal of Maritime Economics, 4: 281-300.

Brown, S.J. and D.S. Sibley (1986) The Theory of Public Utility Pricing. Cambridge University Press: Cambridge.

Burley, K. (1968) British Shipping and Australia, 1920-1939. Cambridge University Press: Cambridge.

Button, K. (1996) "Liberalising European Aviation: Is There an Empty Core Problem?" Journal of Transport Economics and Policy, 30: 275-291.

Cafruny, A.W. (1987) Ruling the Waves: The Political Economy of International Shipping. University of California Press: Berkeley.

Chandler, A.D. (1977) The Invisible Hand: The Managerial Revolution in American Business. Harvard University Press: Cambridge.

Clarke, R.L. (1997) "An Analysis of the International Ocean Shipping Conferences System," Transportation Journal, 36: 17-29.

Clyde, P.S. and J.D. Reitzes (1998) "Market Power and Collusion in the Ocean Shipping Industry: Is a Bigger Cartel a Better Cartel?” Economic Inquiry, 36: 292-304.

Davies, J.E. (1994) “The Evolution of Canadian Liner Shipping Policy," Maritime Policy and Management, 21: 77-87.

Davies, J.E., C.S. Pirrong, W. Sjostrom, and G. Yarrow (1995) "Stability and Related Problems in Liner Shipping: An Economic Overview," Hearing before the Committee on Commerce, Science, and Transportation, U.S. Senate, 104th Congress, 1st Session, November.

Davies, P.N. (1973) The Trade Makers: Elder Dempster in West Africa. George Allen \& Unwin: London.

De Long, J.B. (1991) “Did J.P. Morgan's Men Add Value?” in P. Temin (ed), Inside the Business Enterprise: Historical Perspectives on the Use of Information. University of Chicago Press: Chicago.

Deltas, G., K. Serfes, and R. Sicotte (1999) "American Shipping Cartels in the Pre-World War I Era," Research in Economic History, 16: 1-38.

Dyos, H.J. and D.H. Aldcroft (1969) British Transport: An Economic Survey from the Seventeenth Century to Twentieth. Leicester University Press: Leicester. 
Farthing, B. (1993) International Shipping: An Introduction to the Policies, Politics, and Institutions of the Maritime World. (ed. 2). Lloyd's of London Press: London.

Fields, M.J. (1932) "The International Mercantile Marine Company - An Ill-Conceived Trust," Journal of Business, 5: 268-282.

Fleming, D.K. (2002) "Reflections on the History of US Cargo Liner Service (Part I)," International Journal of Maritime Economics, 4: 369-389.

Fox, N.R. (1992) “An Empirical Analysis of Ocean Liner Shipping," International Journal of Transport Economics, 19: 205-225.

Fox, N.R. (1994) "An Oligopoly Model of Ocean Liner Service," Review of Industrial Organization, 9: 343-355.

Fox, N.R. (1995) "Some Effects of the U.S. Shipping Act of 1984 on Ocean Liner Shipping Conferences," Journal of Maritime Law and Commerce, 26: 531-544.

Fox, N.R. and L.J. White (1997) "U.S. Ocean Shipping Policy: Going Against the Tide," Annals of the American Academy of Political and Social Sciences, 533: 75-86.

Frank, R.H. "When are Price Differentials Discriminatory?" Journal of Policy Analysis and Management, 2: 238-255.

Fusillo, M. (2003) "Excess Capacity and Entry Deterrence: The Case of Ocean Liner Shipping Markets," Maritime Economics \& Logistics, 5: 100-115.

Gardner, B. (1997) "EU Competition Policy and Liner Shipping Conferences," Journal of Transport Economics and Policy, 31: 317-324.

Gordon, J.S. (1969) "Shipping Regulation and the Federal Maritime Commission, Part 1," University of Chicago Law Review, 37: 90-158.

Graham, M.G. (1981) "Shipping Economics, With Special Reference to Liner Shipping," in M.B.F. Ranken (ed), Greenwich Forum VI: World Shipping in the 1990s. Westbury House: Guildford, Surrey.

Graham, M.G. (1998) "Stability and Competition in Intermodal Container Shipping: Finding a Balance," Maritime Policy and Management, 25: 129-147.

Greenhill, R. (1977) “Shipping, 1850-1914,” in D.C.M. Platt (ed), Business Imperialism, 1840-1930: An Inquiry Based on British Experience in Latin America. Oxford University Press: Oxford.

Greenhill, R. (1998) "Competition or Co-operation in the Global Shipping Industry: The Origins and Impact of the Conference System for British Ship owners before 1914." Research in Maritime History, 14: 53-80.

Grossman, W.L. (1956) Ocean Freight Rates. Cornell Maritime Press: Cambridge. 
Haralambides, H.E., P. Cariou, and M. Benacchio (2002) "Costs, Benefits, and Pricing of Dedicated Container Terminals," International Journal of Maritime Economics, 4: 21-34.

Harley, C.K. (1971) "The Shift from Sailing Ships to Steamships, 1850-1890: A Study in Technological Change and its Diffusion," in D.N. McCloskey (ed), Essays on a Mature Economy: Britain after 1840. Princeton University Press: Princeton.

Heaver, T. (1993) "Workable Competition, Politics, and Competition Policy in Liner Shipping," in K.M. Gwilliam (ed), Current Issues in Maritime Economics. Kluwer Academic: Dordrecht.

Helmick, J.S. (2000) Statement of Jon S. Helmick on the Current State and Future Prospects of the Liner Shipping Industry before the Subcommittee on Coast Guard and Maritime Transportation, Committee on Transportation and Infrastructure, U.S. House of Representatives. May 3, http://www.house.gov/transportation/cgmt/hearing/05-03$\underline{00 / \text { helmick.htm }}$

Herman, A. (1983) Shipping Conferences. Kluwer Law and Taxation Publishers: Antwerp.

Hudson, L.G. (1981) "Prospects for the Liner Industry," in M.B.F. Ranken (ed), Greenwich Forum VI: World Shipping in the 1990s. Westbury House: Guildford, Surrey.

Hyde, FE. (1957) Blue Funnel: A History of Alfred Holt and Company of Liverpool from 1865 to 1914. Liverpool University Press: Liverpool.

Hyde, F.E. (1967) Shipping Enterprise and Management 1830-1939. Liverpool University Press: Liverpool.

Jankowski, W.B. (1989) “The Development of Liner Shipping Conferences," International Journal of Transport Economics, 16: 313-328.

Jansson, J.O. and D. Shneerson (1987) Liner Shipping Economics. Chapman and Hall: London.

Jenkins, H.W., Jr. (1996) “Antitrust Pirates the High Seas,” Wall Street Journal, December 3 .

Jones, S. (1985) "George Benjamin Dodwell: A Shipping Agent in the Far East: 18721908," Journal of Transport History, (series 3), 6: 23-40.

Kirkaldy, A. (1914) British Shipping. Kegan Paul, Trench, Trubner: London.

Larner, R. (1975) "Public Policy in the Ocean Freight Industry," in A. Phillips (ed), Promoting Competition in Regulated Markets. Brookings Institution: Washington, D.C.

Letwin, W. (1965) Law and Economic Policy in America: The Evolution of the Sherman Antitrust Act. University of Chicago Press: Chicago. 
Leubuscher, C. (1963) The West African Shipping Trade: 1909-1959. A.W. Sythoff: Leyden.

Levy, H. (1935) Industrial Germany. Cambridge University Press: Cambridge.

Lewis, W.A. (1949) Overhead Costs: Some Essays in Economic Analysis. Rinehart: New York.

Lloyd's of London. (1995) Lloyd's Maritime Atlas of World Ports and Shipping Places. Eighteenth Edition. Lloyd's of London Press: Colchester, England.

Ludwick, E.M. (1983) Shipping Conferences: Survey of Users' Views. Consumer and Corporate Affairs Canada: Ottawa.

MacGregor, D.R. (1961) The China Bird: The History of Captain Killick and One Hundred Years of Sail and Steam. Chatto and Windus: London.

Maddison, A. (1991) Dynamic Forces in Capitalist Development: A Long-Run Comparative View. Oxford University Press: Oxford.

Marín, P.L. and R. Sicotte (2003) "Exclusive Contracts and Market Power: Evidence from Ocean Shipping,” Journal of Industrial Economics, 51: 193-214.

Marriner, S. and F.E. Hyde (1967) The Senior: John Samuel Swire, 1825-1898, Management in Far Eastern Shipping Trades. Liverpool University Press: Liverpool.

Marshall, A. (1921) Industry and Trade. Macmillan: London.

Marx, D., Jr. (1953) International Shipping Cartels. Princeton University Press: Princeton.

McChesney, F.S. and W.F. Shughart, II (1995) The Causes and Consequences of Antitrust: The Public-Choice Perspective. University of Chicago Press: Chicago.

McConville, J. (1994) "Synopsis of the General Discussion,” In H.J. Molenaar and E. Van de Voorde (eds), Competition Policy in Liner Shipping. University of Antwerp: Antwerp.

McCutcheon, B. (1997) "Do Meetings in Smoke-Filled Rooms Facilitate Collusion?" Journal of Political Economy, 105: 330-50.

McGee, J.S. (1960) "Ocean Freight Conferences and American Merchant Marine," University of Chicago Law Review, 27: 191-314.

McGee, J.S. (1980) "Predatory Pricing Revisited," Journal of Law and Economics, 23: 289-330.

McWilliams, A. (1990) "Rethinking Horizontal Market Restrictions: In Defense of Cooperation in Empty Core Markets," Quarterly Review of Economics and Business, 30: 3-14. 
McWilliams, A. and K. Keith (1994) "The Genesis of the Trusts: Rationalization in Empty Core Markets,” International Journal of Industrial Organization, 12: 245-267.

Midoro, R. and A. Pitto (2000) "A Critical Evaluation of Strategic Alliances in Liner Shipping," Maritime Policy and Management, 27: 31-40.

Mitchell, B.R. (1982) International Historical Statistics: Africa and Asia. New York University Press: New York.

Murray, M. (1953) Union-Castle Chronicle, 1853-1953. Longmans, Green: London.

Nannes, J.M. (2000) Statement of John M. Nannes before the House Committee on the Judiciary on H.R. 3138, The Free Market Antitrust Immunity Reform Act of 1999. March 22 http://www.usdoj.gov/atr/public/testimony/4377.pdf.

Officer, L. (1971) "Monopoly and Monopolistic Competition in the International Transportation Industry," Western Economic Journal, 9: 134-56.

Organisation for Economic Co-operation and Development [OECD]. (2001) "Regulatory Issues in International Maritime Transport," Paris: Organisation for Economic Cooperation and Development http://www.oecd.org/dataoecd/0/63/2065436.pdf

Organisation for Economic Co-operation and Development (2002) "Competition Policy in Liner Shipping," DSTI/DOT(2002)2. Paris: Organisation for Economic Co-operation and Development http://www.oecd.org/dataoecd/13/46/2553902.pdf

Ortiz Blanco, L. and B. van Houtte (1996) EC Competition Law in the Transport Sector. Clarendon Press: Oxford.

Pirrong, S.C. (1992) "An Application of Core Theory to the Analysis of Ocean Shipping Markets," Journal of Law and Economics, 35: 89-131.

Plant, A. (1963) "Economic Development, 1795-1921," in E.A. Walker (ed), Cambridge History of the British Empire, Second Edition, Vol. 8, South Africa, Rhodesia and the High Commission Territories. Cambridge University Press: Cambridge.

Podolny, J.M. and F. Scott Morton (1999) "Social Status, Entry and Predation: The Case of British Shipping Cartels 1879-1929," Journal of Industrial Economics, 47: 41-67.

Productivity Commission (1999) International Liner Cargo Shipping: A Review of Part X of the Trade Practices Act 1974, Report no. 9. Canberra: AusInfo.

Reitzes, J.D. and K.L. Sheran (2002) "Rolling Seas in Liner Shipping," Review of Industrial Organization 20: 51-59.

Rill, J.F. (1991) Statement of James F. Rill, Assistant Attorney General Antitrust Division, United States Department of Justice, before the Advisory Commission on Conferences in Ocean Shipping. Washington, D.C.: Department of Justice, September 13. 
Ryoo, D-K. and H.A. Thanopoulou (1999) "Liner Alliances in the Globalization Era: A Strategic Tool for Asian Container Carriers," Maritime Policy and Management, 26: 349367.

Sabel, C.F. (1991) “Comment on J. Bradford DeLong, 'Did J.P. Morgan's Men Add Value?"' in P. Temin (ed), Inside the Business Enterprise: Historical Perspectives on the Use of Information. University of Chicago Press: Chicago.

Scherer, F.M. (1979) “On Maritime Shipping Conferences," in National Commission for the Review of Antitrust Laws and Procedures, Report to the President and the Attorney General, vol. 2, Washington, D.C.: GPO, January 22.

Scott Morton, F. (1997) "Entry and Predation: British Shipping Cartels, 1879-1929," Journal of Economics \& Management Strategy, 6: 679-724.

Sheppard, E.J. and D. Seidman (2001) "Ocean Shipping Alliances: The Wave of the Future?” International Journal of Maritime Economics, 3: 351-367.

Sicotte, R. (1999) "Economic Crisis and Political Response: The Political Economy of the Shipping Act of 1916," Journal of Economic History, 59: 861-884.

Sjostrom, W. (1986) Price Fixing Agreements and the Existence of Equilibrium: The Case of Liner Freight Conferences. Unpublished Ph.D. dissertation, University of Washington.

Sjostrom, W. (1988) "Monopoly Exclusion of Lower Cost Entry: Loyalty Contracts in Ocean Shipping Conferences," Journal of Transport Economics and Policy, 22: 339-344.

Sjostrom, W. (1989a) "Collusion in Ocean Shipping: A Test of Monopoly and Empty Core Models," Journal of Political Economy, 97: 1160-1179.

Sjostrom, W. (1989b) "On the Origin of Shipping Conferences: Excess Capacity and the Opening of the Suez Canal," International Journal of Transport Economics, 16: 329-335.

Sjostrom, W. (1992) "Price Discrimination by Shipping Conferences," Logistics and Transportation Review, 28: 207-215.

Sjostrom, W. (1993) "Antitrust Immunity for Shipping Conferences: An Empty Core Approach," Antitrust Bulletin, 38: 419-423.

Sjostrom, W. (1998) "Competition Law in the European Union and the United States," in P. Newman (ed), The New Palgrave Dictionary of Economics and the Law, vol. 1. Macmillan: London.

Sloan, E.W. (1998) "The First (and Very Secret) International Steamship Cartel, 18501856," Research in Maritime History, 14: 29-52.

Smith, J.R. (1906a) "Ocean Freight Rates and their Control through Combinations," Political Science Quarterly, 21: 237-263. 
Smith, J.R. (1906b) "Ocean Freight Rates and their Control by Line Carriers," Journal of Political Economy, 14: 525-41.

Smith, T.K. (1995) “Why Air Travel Doesn’t Work,” Fortune (April 3):26-36.

Song, D-W. and P.M. Panayides (2002) "A Conceptual Application of Cooperative Game Theory to Liner Shipping Strategic Alliances," Maritime Policy and Management, 29: 285-301.

Stigler, G.J. (1968) The Organization of Industry. Irwin: Homewood, Illinois.

Stopford, M. (1997) Maritime Economics. (ed. 2). Routledge: London.

Stragier, J. (2002) "Recent developments in EU Competition Policy in the Maritime Sector," Speech to the Shipping Forecast Conference, London, 25 April http://europa.eu.int/comm/competition/speeches/text/sp2002 015 en.pdf.

Sturmey, S.G. (1967) "Economics and International Liner Services," Journal of Transport Economics and Policy, 1: 190-203.

Telser, L. (1978) Economic Theory and the Core. University of Chicago Press: Chicago.

Telser, L. (1987) A Theory of Efficient Cooperation and Competition. Cambridge University Press: Cambridge.

Telser, L. (1994) "The Usefulness of Core Theory in Economics," Journal of Economic Perspectives, 8: 151-164.

Telser, L. (1996) “Competition and the Core,” Journal of Political Economy, 104: 85-107.

Thanopoulou, H.A., D-K. Ryoo, and T-W. Lee (1999) "Korean Liner Shipping in the Era of Global Alliances," Maritime Policy and Management, 26: 209-229.

Trace, K. (2002) "Globalisation of Container Shipping: Implications for the North-South Liner Shipping Trades," Paper presented at XIII World Congress of Economic History, Buenos Aires, July http://www.eh.net/XIIICongress/cd/papers/24Trace173.pdf

U.S. Department of Justice Antitrust Division (1990) The Department of Justice Analysis of the Impact of the Shipping Act of 1984, March. Department of Justice: Washington, D.C.

U.S. Federal Maritime Commission [FMC] (1982) Approved Conference, Rate, Interconference, Charter, Rationalization, Pooling and Joint Service Agreements. Federal Maritime Commission: Washington, D.C.

U.S. Federal Maritime Commission (1989) Section 18 Report on the Shipping Act of 1984, September. Federal Maritime Commission: Washington, D.C.

U.S. Federal Maritime Commission (2001) "The Impact of the Ocean Shipping Reform Act of 1998," September, http://www.fmc.gov/OSRA REPORT/OSRA Study.pdf 
U.S. Federal Trade Commission (1989) An Analysis of the Maritime Industry and the Effects of the 1984 Shipping Act, November. Federal Trade Commission: Washington, D.C.

Walters, A.A. (1978) "Gains from Deregulation of Ocean Shipping," in Northwestern University Transportation Center Forum, Proceedings: In Search of a Rational Liner Shipping Policy, March 13-14. Transportation Center, Northwestern University: Evanston, Illinois.

Wiley, J.S., Jr. (1987) “Antitrust and Core Theory," University of Chicago Law Review, 54: 556-589.

Wilson, T. (1962) "Restrictive Practices," in J.P. Miller (ed), Competition, Cartels and their Regulation. North Holland: Amsterdam.

Yamey, B.S. (1972) "Predatory Price Cutting: Notes and Comments," Journal of Law and Economics, 15: 129-42.

Yong, J-S. (1996) "Excluding Capacity-Constrained Entrants Through Exclusive Dealing: Theory and an Application to Ocean Shipping," Journal of Industrial Economics, 44: 115129. 